\title{
La política como vocación de Max Weber. Breve relectura en su centenario
}

\section{POR MARÍA VERÓNICA PICCONE $(*)$}

Sumario: I. Introducción.- II. Las formas de legitimidad.- III. La dominación legal con administración burocrática.- IV. La dominación carismática.- V. Los "convocados": medios de vida y ética.- VI. Palabras finales.- VII. Bibliografía.

Resumen: el artículo reflexiona sobre algunas categorías centrales elaboradas por Max Weber en el centenario de su muerte. Aborda algunos conceptos desarrollados en "La política como vocación", que fue originalmente presentada en una conferencia durante 1919. Además, profundiza la lectura de los tipos ideales de dominación carismática y racional legal abordados en Economía y sociedad. Finalmente recupera los conceptos de ética de la convicción y ética de la responsabilidad como valiosos instrumentos para el análisis de la política actual.

Palabras claves: política - carisma - ética

La politica come professione di Max Weber. Breve rilascio nel suo centenario

Sommario: l'articolo riflette alcune categorie centrali elaborate da Max Weber nel centenario della sua morte. Affronta alcuni concetti sviluppati in "La politica come professione", che è stato presentato originariamente in una conferenza nel 1919. Inoltre, approfondisce la lettura dei tipi ideali di dominio legale carismatico e razionale affrontati in Economia e società. Infine, recupera i concetti di etica della convinzione e dell'etica della responsabilità come strumenti preziosi per l'analisi della politica attuale.

Parole chiave: politica - carisma - etica

(*) Prof. Adjunta ordinaria, Derecho Político, Cátedra III, Facultad de Ciencias Jurídicas y Sociales, Universidad Nacional de la Plata, UNLP. Prof. Adjunta regular Derecho Constitucional y Derechos Humanos, Universidad Nacional de Río Negro, UNRN. Investigadora del Centro Interdisciplinario de Estudios Sobre Derechos Inclusión y Sociedad, CIEDIS/UNRN. 


\section{Introducción}

Max Weber nació en 1864 en Erfurt, ciudad ubicada en el centro geográfico de la actual Alemania, entonces Prusia. Fue profesor en las universidades de Friburgo (1894-1895) y Heidelberg (1895-1897), aunque debió suspender sus actividades académicas por problemas de salud. Un año antes de su muerte empezó a dictar clases en la ciudad de Múnich. Allí, en 1919, participó de un ciclo de conferencias a cargo de diversos oradores a pedido de la Asociación Libre de Estudiantes, en donde expuso las ideas que son recogidas en "La ciencia como vocación" y en la "La política como vocación".

Las reflexiones de Weber expresadas en "La política como vocación" -el texto original, en alemán "Politik als beruf", fue publicado en 1919(1)- hace cien años, se producen en un momento en que el Imperio alemán (en alemán Deutsches Reich) se ve obligado a suscribir el Tratado de Versalles consecuencia de la derrota en la Primera Guerra Mundial, a la vez que se organiza como república luego de la abdicación de Guillermo III, dejando atrás una monarquía constitucional todavía signada por el legado de Otto von Bismarck y dando lugar a una república parlamentaria. Max Weber trabajo como consultor tanto en el tratado de armisticio como en la comisión de redacción de la Constitución de Weimar, lo que deja rastros en "La política como vocación" no sólo a través de algunas reflexiones sobre la coyuntura sino, principalmente, dotando de sentido apreciaciones más generales sobre las características de la política como actividad humana.

En "La política como vocación" Weber reflexiona sobre las características de la actividad política; las condiciones y aptitudes individuales necesarias para realizar esa actividad humana y, la ética propia o específica de la profesión.

Para el autor, la "política" como actividad humana es "(...) la dirección o la influencia sobre la dirección de (...) un estado" (1982, p. 309) o sea, de una asociación política que se distingue de otras asociaciones por su medio específico: la violencia física. Quien hace política, dice Weber “(...) aspira al poder; al poder como medio para la consecución de otros fines (idealistas o egoístas) o al 'poder por el poder', para gozar del sentimiento de prestigio que le confiere" (1982, p. 309). Los fines, la cavilación del eventual "deber ser" de la política, no interesan al autor, aunque veremos, algunos de sus valores sobre ellos se pueden inferir del texto.

De las tres formas de justificación interna del ejercicio esta "dominación de hombres sobre hombres" la que interesa particularmente es la "carismática"

(1) Utilizamos aquí la traducción de Weber, Max (1982), "La política como vocación”, en Weber, Max, Escritos Políticos II, traducción de F. Rubio Llorente et. al. México: Folios Ediciones (pp. 308-364). 
puesto que en este tipo puro se manifiesta según Weber en su forma más alta, la idea de vocación.

Weber refiere en el texto algunos rasgos básicos de estos tres tipos puros, pero su desarrollo se encuentra en Economía y sociedad, obra póstuma y tal vez la más relevante junto con La ética protestante y el espíritu del capitalismo. Esto empero, como veremos, no significa que la idea de vocación sólo se relacione con el tipo puro de dominación carismática.

\section{Las formas de legitimidad}

Economía y Sociedad (2002) fue publicado por primera vez en 1922, editado por Mariana Weber, dos años después de la muerte de su autor. Afirma Johannes Winckelmann en el prólogo de la segunda edición alemana — de 1955 y en la cual la traducción que utilizamos se basa- que existen dudas respecto del momento preciso en que fueron redactados los originales, así como discusiones sobre la estructura de la obra, por cierto, inacabada.

¿A qué llama Weber "dominación”? a "(...) la probabilidad de encontrar obediencia dentro de un grupo determinado para mandatos específicos" (Weber, 2002, p. 170). La "dominación" se distingue del "poder" o la influencia sobre otros hombres que puede tener razones más amplias. De la lectura del texto se desprende que hay "un mínimo" de componente "voluntario" en la dominación en tanto que en la definición de "poder" el autor destaca el carácter de imposición. Dice "Poder significa la probabilidad de imponer la propia voluntad, dentro de una relación social, aun contra toda resistencia y cualquiera que sea el fundamento de esa probabilidad" (Weber, 2002, p. 43)(2).

La dominación, entonces, es una especie de poder que se asienta en "Un determinado mínimo de voluntad de obediencia, o sea de interés (externo o interno) en obedecer, es esencial en toda relación auténtica de autoridad" (Weber, 2002, p. 170)(3).

Toda dominación sobre un grupo de hombres requiere "de un modo normal" de un cuadro administrativo que realiza - o quien domina espera que realicelas acciones necesarias para ejecutar esos mandatos. El tipo de dominación está en buena medida caracterizado por aquel motivo o fundamento que hace que este cuadro administrativo obedezca y que a la vez funcione como ejecutor de los

(2) El destacado en el original.

(3) Más allá de ello, nunca debe olvidarse que, si se trata de la dominación de una asociación política o estado, la violencia es su medio específico. 
mandatos del dominador sobre otros (Weber, 2002, p. 170). Pero, la existencia de motivos para obedecer dentro del cuadro administrativo - ya sean materiales, afectivos o racionales con arreglo a valores- no satisfacen completamente a cualquier dominación que se precie. Lo decisivo es promover y lograr que se crea que "existen motivos legítimos" tanto para emitir mandatos, como una obligación de obedecerlos. Quien domina aspira a que sus mandatos sean vistos como legítimos -y que, por ello, sean obedecidos- de acuerdo con tres formas típicas, que a su vez dan lugar a: diferentes formas de obediencia, diversos cuadros administrativos típicos y disímiles formas de ejercicio de la dominación. En Economía y sociedad se percibe la preocupación de Weber por construir "conceptos claros" sobre un tema con muchos matices (Weber, 2002, p. 171)(4).

Debe tenerse siempre presente que "La "legitimidad" de una dominación debe considerarse sólo como una probabilidad (...)" (Weber, 2002, p. 171), es decir, deber ser considerada en general de esa manera y aceptada por un número importante, pero en ningún modo absoluto, de personas. No importa que algunos finjan y otros "crean" por conveniencia. "(...) su propia pretensión de legitimidad, por su índole la hace "válida" en grado relevante, consolida su existencia y codetermina la naturaleza del medio de dominación" (Weber, 2002, p. 171), es decir, determina la forma del vínculo entre el "soberano y el cuadro administrativo" (Weber, 2002, p. 172)(5).

De acuerdo con el fundamento primario o principal de su legitimidad, existen tres "tipos puros" de dominación legítima:

- La dominación legítima de carácter racional que se fundamenta en la creencia en la legalidad de ordenaciones estatuidas y de los derechos de mando de los llamados por esas ordenaciones a ejercer la autoridad (autoridad legal) (Weber, 2002, p. 172), o sea, se cree en las leyes, los estatutos, la constitución y en aquellos que resultan "investidos" de autoridad por ellos.

- La dominación legítima de carácter tradicional basada en la "creencia cotidiana en la santidad de las tradiciones que rigieron desde lejanos tiempos y en la legitimidad de los señalados por esa tradición para ejercer la autoridad (autoridad tradicional)" (Weber, 2002, p. 172) y,

(4) Por supuesto, siempre hablando de tipos ideales. El desarrollo de este constructo se encuentra en Economía y Sociedad.

(5) Weber introduce a continuación el concepto de "Obediencia", que "significa que la acción del que obedece transcurre como si el contenido del mandato se hubiera convertido, por sí mismo, en máxima de su conducta" (2002, p. 172). 
- La dominación legítima de carácter carismático, que se asienta en "la entrega extracotidiana a la santidad, heroísmo o ejemplaridad de una persona y a las ordenaciones por ella creadas o reveladas (llamada) (autoridad carismática)" (Weber, 2002, p. 172), o sea, se cree directamente en la persona llamada a mandar, el caudillo.

Weber emprende la tarea de determinar conceptualmente las características de las formas "más puras" de cada una de estas dominaciones típicas. De estas características, focalizaremos particularmente aquellas que permiten distinguir los tipos puros de dominación legítima racional, y de dominación legítima carismática, haciendo hincapié en algunos conceptos especialmente vinculados a lo tratado por Weber en "La política como vocación".

\section{La dominación legal con administración burocrática}

Este tipo de dominación es el propio de la modernidad. Para Weber, el tipo puro se asienta en la validez de un conjunto de ideas vinculadas entre sí que en lo fundamental remiten a la posibilidad de estatuir derechos en un sistema que será respetado en general y conformado por reglas abstractas que serán meramente aplicadas a los casos concretos. Quien ejerce la dominación también aparece sometido a esas reglas e investido de autoridad por las mismas y, quienes son dominados lo son en función de la investidura del líder de una forma impersonal, y sólo respecto del acotado marco en que aquel está autorizado a mandar (Weber, 2002, p. 174). La forma de dominación territorial que se configura a partir del proceso de las revoluciones burguesas es un ejemplo del conjunto de ideas que anida en este de dominación(6).

El cuadro administrativo típico de esta dominación legal recibe el nombre de burocracia. En el pensamiento de Weber esta es una organización jerárquica compuesta por funcionarios con competencias específicas asignadas a un cargo individual -monocracia-. Su compromiso y su deber sólo existen en el ámbito o espacio propio del cargo que ejercen y están establecidas en un contrato -o reglamento- al que se someten poniendo a disposición sus conocimientos técnicos a cambio de una contraprestación dineraria (salario) (7) y aceptando la dirección jerárquica de quienes ocupan puestos superiores. El trabajo industrial a partir del siglo XIX se organiza bajo estos parámetros, así como el empleo público. Las personas son "libres" por fuera del contrato que suscribieron - que en realidad es un

(6) El pensamiento liberal y la falaz dicotomía entre el ámbito público y privado, con límites precisos al accionar del Estado en esta última, remiten a este tipo de dominación. También, la propia idea de estado de derecho a nuestra consideración se vincula mejor con este tipo que con otros.

(7) Estas dos características los convierten en profesionales según la terminología de Weber. 
contrato de adhesión y no cláusulas consensuadas- y desarrollan expectativas de ascenso en la jerarquía de la organización. En nuestro medio, más que la denominación de funcionarios correspondería la de empleados, tanto en la estructura estatal como en la empresa capitalista.

"La administración burocrática pura, o sea, la administración burocrática atenida al expediente es (...) la forma más racional de ejercer una dominación" (Weber, 2002, p. 178) y es para Weber inseparable de la "administración de masas". Una vez burocratizado el funcionamiento de una sociedad de masas, el sistema burocrático se vuelve ineludible - "compulsivo" dice Weber-: no podemos siquiera alimentarnos sin una organización burocrática y, por otra parte, al aparato burocrático le importa poco quien lo domina lo que entendemos es uno de sus componentes tendencialmente antidemocráticos. Este es uno es los temas más interesantes de discusión. Al respecto Giddens afirma que

(...) existe una antinomia básica entre la democracia y la burocracia, ya que el desarrollo de las disposiciones legales abstractas necesarias para poner en funcionamiento los propios procedimientos democráticos da lugar a la creación de una nueva modalidad de monopolio atrincherado (2002, p. 26).

Por otra parte, la compulsión del que habla el autor permitiría discutir la calidad de "libre" del ejercicio de cualquier función burocrática. Es decir, en la sociedad de masas en el mejor de los casos se puede elegir a que establecimiento burocrático servir, pero en la mayoría de los casos las personas están obligadas a servir a alguno para subsistir, lo que lo vuelve un punto interesante para la discusión con el pensamiento marxiano y la compulsión al trabajo. La burocracia adquiere, entonces, un "(...) carácter fatal (...) como medula de toda administración de masas" (Weber, 2002, p. 179), carácter reforzado porque resulta imposible doblegar su saber técnico y su estructura sin contraponer a ello otra similar.

Sin embargo, no debe perderse de vista que no es el componente burocrático el que determina la existencia de un tipo de dominación racional legal, sino que es un cuadro administrativo que principalmente se presenta en este tipo ideal de dominación, pero puede darse en otros.

Como dice Weber:

Tipos muy importantes de dominación racional pertenecen formalmente por su dirigente a otros tipos (carismático-hereditarios: monarquía hereditaria; carismático-plebiscitarios: presidente); otros son materialmente racionales en muchas de sus partes, pero se encuentran construidos según una forma intermedia entre la burocracia y el caris- 
matismo (gobiernos de gabinete); otros, por último, están conducidos (ministerios de partido) por los dirigentes (burocráticos o carismáticos) de otras asociaciones (partidos). El tipo de la administración legal y racional es susceptible de aplicación universal, y es lo importante en la vida cotidiana. Pues para la vida cotidiana dominación es principalmente 'administración' (2002, p. 175) (8).

Del párrafo citado supra se desprenden algunas cuestiones claras: a) lo determinante para definir a que "tipo puro" se acerca más una específica dominación es en qué se asienta la creencia en el dirigente y no el cuadro administrativo que lo acompaña; b) la burocracia o la administración racional legal es útil, a cualquier tipo de dominación. Ahora, en el medio de esas certezas, consideramos que Weber no conceptualiza claramente los ejemplos que brinda, a mi modo de ver alejándose de los tipos ideales que construye o, no dando cuenta de las razones de sus afirmaciones, aunque infra se vislumbran algunas posibles precisiones.

Luego, si "La dominación burocrática tiene, pues, en su cima inevitablemente un elemento, por lo menos, que no es puramente burocrático. Representa tan sólo una categoría de la dominación por medio de un cuadro administrativo especial" (Weber, 2002, p. 177), ¿existe una dominación racional legal propiamente dicha? Aunque existan supuestos de "(...) subordinación total de la población a un aparato burocratizado" (Giddens, 2002, p. 26) como el antiguo Egipto parece siempre que en la cúspide hay algo que va más allá de la legitimidad racional legal.

\section{La dominación carismática}

El carisma es en el pensamiento de Weber la posesión de una cualidad considerada por otros como extraordinaria. Lo excepcional no es la personalidad o características de una persona, sino que otros vean a esa persona como una especie de dios o semidiós: “(...) lo que importa es cómo se valora 'por los dominados' carismáticos, por los 'adeptos"' (Weber, 2002, p. 192).

Y, aunque pudiera esa valoración justificarse en parte en alguna cualidad medianamente objetiva, el carácter emotivo e irracional de la relación carismática borra en inicio toda racionalidad, lo que convierte a este tipo ideal en el opuesto al tipo de dominación racional con administración burocrática, cimentado en características opuestas (9).

(8) El destacado es del original.

(9) También se opone a la dominación tradicional puesto que tanto esta como la racional son ordinarias. 
Basada en las emociones, el reconocimiento (en el carisma genuino) no es el fundamento de la legitimidad, sino un deber de los llamados, en méritos de la vocación y de la corroboración, a reconocer esa cualidad (Weber, 2002, p. 194) (10). O sea, que hay "llamados" (11) a ejercer el carisma y llamados a reconocerlo y obedecerlo.

El cuadro administrativo típico de esta dominación también es escogido por sus cualidades carismáticas y ejerce sus funciones sin jurisdicción ni competencias.

Ahora, sí la creencia siempre se asienta en los dominados, el líder carismático debe también entregarse a la causa. Esto lo dota de una capacidad revolucionaria por dos motivos; el poder que le otorga la entrega personal de los dominados y, su propia necesidad de reactualizar en forma permanente su extraordinariedad. El imperio carismático:

(...) subvierte el pasado (dentro de su esfera) y es en este sentido específicamente revolucionaria. No conoce ninguna apropiación del poder de mando, al modo de la propiedad de otros bienes, ni por los señores ni por poderes estamentales, sino que es legítima en tanto que el carisma personal 'rige' por su corroboración, es decir, en tanto que encuentra reconocimiento, y 'han menester de ella' los hombres de confianza, discípulos, séquito; y sólo por la duración de su confirmación carismática (Weber, 2002, p. 195) (12).

Para Weber "El carisma es la gran fuerza revolucionaria (...)" (2002, pp. 196197) y, por ello, Weber se muestra preocupado por la ausencia de un liderazgo de este tipo al momento de dictar la conferencia "La política como vocación" en 1919.

\section{Los "convocados": medios de vida y ética}

Weber identifica aquí vocación con "llamado". El líder carismático es aquella persona percibida como "convocada" para ser líder, conductor de hombres, y que es obedecido porque se cree en él, sin mediación de costumbres o estatutos legales. La dominación carismática típica reúne así una creencia de rasgos místicos o mágicos en los que obedecen, pero, fundamental también, requiere un líder que se entregue a la tarea con su vida, que "vive para su obra" (Weber, 1982, p. 311) ejemplificados en el caudillaje político por el "demagogo libre" de la ciudad estado, el "jefe de partido" en la política parlamentaria y para nosotros, ciertos líderes

(10) Weber volverá sobre este punto más adelante para tratar el supuesto de transformación antiautoritaria del carisma.

(11) En el sentido más propio contenido en "La política como vocación".

(12) El destacado con comillas es del original. 
populistas. Estos políticos por vocación pretenden el poder para gobernar por sí mismos, en su propio nombre, como un Napoleón.

Como hemos dicho, Weber señala que, en la empresa política, la lucha por el poder y la influencia, requiere, además, de medios auxiliares: cuadros administrativos y recursos materiales que a lo largo de la historia despliegan características y vínculos particulares hasta llegar a la apropiación completa de los recursos materiales por parte de los príncipes en el proceso que da lugar al surgimiento de los estados modernos (13).

Es este proceso de apropiación del capital económico, en términos de Pierre Bourdieu (2002), el que da lugar a la aparición según Weber de "las primeras categorías de políticos profesionales" (1982, p. 314), pero aquí en un sentido distinto, como políticos que trabajan para otro, al servicio de quien es o aspira a ser líder o al servicio "del partido".

$\mathrm{Al}$ hablar de esta categoría de políticos profesionales Weber introduce una de las ideas más lúcidas y probablemente, más incomodas de "La política como vocación": la inescindible relación entre la política profesional y el dinero. Los "políticos profesionales" en este segundo sentido, son hombres que se dedican plena y exclusivamente a la política y que "viven" —entiéndase, se alimentan, se educan, se sostienen económicamente en sus actividades- a partir de la política, que es su alimento material y espiritual. Hay dos formas de "(...) hacer de la política una profesión", que no se excluyen entre sí y que suelen darse juntas: vivir "para" o vivir "de" la política:

Quien vive "para" la política hace "de ello su vida" en un sentido íntimo; o goza simplemente con el ejercicio del poder que posee, o alimenta su equilibrio y su tranquilidad con la conciencia de haberle dado un sentido a su vida, poniéndola al servicio de "algo" (...) vive "de" la política como profesión quien trata de hacer de ella una fuente duradera de ingresos (...) (Weber, 1982, p. 316) (14).

Aunque como dijimos estas formas no son excluyentes para el autor, la primera sólo es factible a través del reclutamiento plutocrático de quienes viven de rentas -fundamentalmente no deben trabajar de ninguna manera para conseguirlas-lo que hace que Weber, se incline por el segundo modo (15), que hace imprescindible conseguir cargos u otras prebendas como retribución profesional. Esta reflexión,

(13) Por supuesto, si alguien se apropia otro resulta desposeído. Al respecto, fuera de las obras de Weber, sugerimos el texto "Espíritus del Estado" de Pierre Bourdieu citado en la bibliografía.

(14) El destacado es del original.

(15) Para Weber la empresa política es siempre una empresa de interesados. 
que infiere sin duda los valores del autor, y está guiada también a la "coyuntura revolucionaria" en que dicta su conferencia. La cuestión de priorizar "la causa" no es abordada en el texto, pero flota sobre él: para Weber, el fin de la política no es el rasgo que da cuenta de la esencia de la actividad, pero eso no quita que no lo tenga, ni que él no tenga preocupaciones al respecto. En su caso, su interés está dado desde el punto de vista político por la consolidación de Alemania como estado, tardía respecto de otras experiencias, motivos bien reflejados por Antony Giddens (2002).

Las páginas siguientes de "La política como vocación", singulares, se dedican a la, en ocasiones, difícil distinción entre el político profesional y el funcionario especializado, "profesiones" diversas pero que operan en tensión sobre las mismas estructuras: los cuadros administrativos del estado, imprescindibles para la dominación y, los partidos políticos como estructuras de aparatos -empresas, máquinas- que pugnan por cargos para ejercer la dominación y también, como modo de subsistencia. Aunque las lógicas últimas de cada actividad son distintas, sobre todo porque el funcionario moderno según Weber, se guía por el honor estamental y la integridad, apareciendo como una especie de freno frente a la corrupción extrema, la balanza requiere de líderes políticos ejerzan una dirección consistente, sólida (16). El deber de los funcionarios es administrar, sine ira et studio y, el de los políticos, sobre todo en el primer sentido del texto, es actuar conforme a la parcialidad y la pasión (Weber, 1982, p. 326) el honor del caudillo político está en "asumir personalmente la responsabilidad de todo lo que hace" (Weber, 1982, p. 328)(17) y no en escudarse en el deber del escritorio.

Las necesidades materiales de la política profesional no anulan la necesidad y el deseo, incluso dentro la militancia del partido, de crecer bajo el influyo de un caudillo carismático, no sólo porque se espera que gane votos y cargos, sino también, por el placer, el goce, que produce trabajar para este tipo de líder (Weber, 1982, p. 336). $\mathrm{Al}$ jefe fuerte se lo obedece con gusto, se goza incluso con la disciplina(18) y disciplina incluso a los parlamentarios. Pero hay sin duda un precio, que es la "desespiritualización" de los seguidores(19), la obediencia ciega: existe un líder que se

(16) Si la burocracia puede ser un freno para el spoils sytem, también tiene tendencias que la pueden hacer antidemocráticas y, sobre todo, es ineficiente de cara a la consolidación de un estado fuerte. Giddens (2002) analiza la tensión entre democracia y burocracia en la obra de Weber.

(17) Por esta distinción los funcionarios son malos políticos.

(18) Weber describe la evolución de los sistemas de partidos de Inglaterra, Estados Unidos y Alemania en unas páginas que no tienen desperdicio y siguen vigentes. El peligro del spoils system en Estados Unidos con partidos cazadores de cargos, sin ningún tipo de convicciones, llenos de diletantes, lacras y corrupción; y, en la empresa alemana, el lastre del funcionariado especializado lleno de aspiraciones políticas al lado de partidos "llenos de convicciones", es decir, ingenuos (Weber, 1982, pp. 342-347).

(19) Su "proletarización espiritual" (Weber, 1982, p. 347). 
convierte en dios indubitado. El precio es aceptable frente a lo opuesto, el "reinado de las camarillas" o sea, en términos de Weber, la "(...) democracia sin caudillos (...) la dominación de 'políticos profesionales' sin vocación" (Weber, 1982, p. 346). Probablemente, el pesado legado administrativo de Bismark esté detrás de estas palabras de Weber, que considera al dominio de la burocracia del partido un agente que fosiliza el desarrollo de éstos y del mismo estado. Como sostiene Giddens:

Una cierta dosis de "cesarismo" resulta inseparable del Estado moderno; un dirigente de partido debe poseer las cualidades carismáticas necesarias para adquirir y mantener la popularidad masiva que puede proporcionarle el éxito electoral. El líder 'plebiscitario' puede utilizar su atractivo carismático para iniciar nuevas líneas políticas y alejarse de los procedimientos burocráticos establecidos (2002, p. 33).

En cambio, la Alemania de Weber se ve acosada por funcionarios que pretenden ocupar el liderazgo político.

La actividad política tiene otras compensaciones, ya que incluso en los humildes políticos profesionales que viven "de" la política sienten el "poder" que implica influir sobre la vida de los otros que los eleva por sobre lo cotidiano (Weber, 1982, p. 349). Pero el poder no es para cualquiera: requiere un conjunto de cualidades y, fundamentalmente, asumir una ética coherente con una actividad cuyo sesgo distintivo es la violencia.

Las cualidades son pasión, sentido de la responsabilidad y mesura. Aunque podría parecer que la pasión y la mesura son cualidades contradictorias, la pasión es imprescindible, porque es la entrega a los dioses y a los demonios de una actividad que consume la vida. Sin embargo, no es un fuego que deba arder hasta consumirse, es un fuego paciente, medido, controlado, porque la política se hace principalmente "con la cabeza". Weber es categórico es esta necesidad de poder alejarse, tomar distancia, para conducir la rueda de la historia y no ser conducido, o mejor arrastrado y arrasado, por ella. Quienes no lo hacen, son "simples diletantes" (Weber, 1982, p. 350) (20).

Los pecados del político son la vanidad, el enamorarse de sí mismo, que es una especie de onanismo público, un narcisismo peligroso (21): el compromiso

(20) El término "diletante" es empleado reiteradamente por Weber, en sentido obviamente peyorativo, para referirse a aquellos que no desarrollan su vocación con disciplina y, al decir de Giddens, reivindican "una competencia universal que no puede poseer" (2002, p. 73).

(21) “(...) cuánta debilidad interior y cuanta impotencia se esconde tras estos gestos ostentosos, pero notablemente vacíos. Dicha actitud es producto de una mezquina y superficial indiferencia frente al sentido de la acción humana" (Weber, 1982, p. 351). 
del político debe estar puesto en "la causa", la finalidad de la actividad, que es en definitiva "una cuestión de fe".

La "causa" debe asumirse de acuerdo con la ética propia de la profesión, ya que, para Weber, no hay una ética absoluta, sino que cada actividad humana tiene su propia ética. Sostiene Aron que "Tanto si se trata de ciencia (22) como de política, Max Weber perseguía siempre el mismo fin: delimitar la ética propia de una determinada actividad, que él suponía debía ser la que se ajustaba a su finalidad peculiar" (Aron, 1979, p. 34) o, mejor, a su medio específico, que en el caso de la política es llanamente la violencia (23).

Weber introduce aquí una de las cuestiones más mentadas de este texto, la distinción entre la ética de la convicción y la ética de la responsabilidad (Weber, 1982, p. 355). Quien actúa conforme la ética de la convicción no se siente responsable de los resultados de sus acciones, aunque los resultados sean malos. ¿Puede el político despreocuparse de las consecuencias, de los resultados últimos de sus acciones? Claramente no, como dice Giddens, la política es una lucha interminable por el poder, por lo que es "(...) fútil cualquier enfoque de la política que se base únicamente en apelaciones éticas de carácter universalista (como las apelaciones a la 'libertad' o a la 'bondad')" (Giddens, 2002, p. 39).

La ética que se corresponde con la política, es una ética que tiene por base la objetividad y la compresión de la naturaleza humana y sus defectos; una ética que distingue medios y fines; una ética que consciente de que no siempre los resultados de las acciones son los esperados; una ética consecuente con la violencia que es su medio específico, una ética consecuencialista. Quien quiera dedicarse a la política debe asumir que su alma está pérdida, debe tener valor para soportar los costos, incluso el de realizar acciones "malas" o "contrarias a sus convicciones" si las considera necesarias para obtener determinada finalidad(24). Un político weberiano debe asumir el precio de un aparato prebendado, debe vender aventuras y botines, difamar adversarios, iniciar guerras, saber rendirse, negociar. En fin, debe tener un cuero muy duro para resistir y no perderse a la vez que entrega su alma.

(22) La ciencia se guía por otra ética. Y, como dice Aron "No se puede ser al mismo tiempo hombre de acción y hombre de estudio sin atentar contra la dignidad de una y otra profesión, sin-faltar a la vocación de ambas" (Aron, 1979, p. 10).

(23) En este sentido Giddens afirma “(...) el carácter político de un grupo puede definirse por el monopolio del uso de la fuerza, que es más un medio que un fin" (2002, p. 50).

(24) Y deberá asumir que muchas veces las acciones emprendidas tienen un resultado opuesto al esperado, hecho sobre el que Weber insiste reiteradamente. 


\section{Entre la rutinización del carisma y su posible transformación autoritaria}

¿Qué sucede cuando lo extraordinario se hace cotidiano? ¿Cuándo el liderazgo se extiende en el tiempo? ¿Cuándo el "guerrero" triunfa en la batalla y le toca la tarea de gobernar? ¿Qué pasa cuando no muere como el Che Guevara y vive para gobernar como Fidel Castro? Weber dice que la dominación carismática se convierte y adquiere las características asociadas a otros tipos de dominación: "se racionaliza (legaliza) o tradicionaliza o ambas en varios aspectos” (2002, p. 197) (25).

En este proceso cobran especial importancia los intereses y deseos del cuadro administrativo que, por una parte, como dice Weber en "La Política como vocación", desean el poder por el poder mismo y, por otra, necesitan sustentos materiales para vivir.

Weber analiza sobre todo este fenómeno a partir de la desaparición del líder carismático y las distintas modalidades de "investir a un sucesor". Un líder carismático que se precie jamás diría "mi único heredero es el pueblo", prueba de que Eva Perón era carismática pero no ejercía un liderazgo político efectivo. Un líder carismático que no muera en batalla o como un mártir, tiene que garantizar su sucesión - aunque sea para gobernar hasta el último día de su mandato constitucional-.

En una dominación carismática no puede escapar a que la mayoría de "(...) los discípulos y seguidores" quiera "vivir materialmente de esta 'vocación' (26), y necesite hacerlo así so pena de desaparecer" (2002, p. 199). De las formas en que esta rutinización del carisma se produce indicadas por Weber, la más interesante para nosotros es la del "carisma objetivado". Es decir, aquel en el cual, por presión de los cuadros administrativos, sobre todo a partir de la creación de cuadros burocráticos, traslada al cargo la misión carismática. Weber admite que este es un supuesto raro y lo asocia a los cargos del clero (2002, p. 201). Finalmente, cuando el carisma se hace ordinario, y esto siempre sucede si se administran masas, la dominación "desemboca en las formas de la dominación cotidiana: patrimonial - en particular, estamental- o burocrática" (2002, pp. 201-201), aunque no se transforma, sino que se hace "menos puro".

El análisis de los que Weber llama en Economía y Sociedad transformación antiautoritaria del carisma es tal vez el punto más atractivo de cara los tiempos actuales. ¿Por qué? Primero porque resulta difícil catalogar, a nuestro entender,

(25) No se convierte en otro tipo de dominación (siempre hablando de tipos ideales) sino que despliega características que el autor en otros apartados identifica como normales en el tipo de dominación racional o en el tradicional.

(26) Como políticos profesionales en el segundo sentido reseñado en "La política como vocación". 
el criterio del autor para determinar en una sociedad de masas, que requiere una administración burocrática y se guía por principios en buena parte estatutarios y racionales, si la dominación es preponderantemente racional legal o carismática.

Es una pregunta que no podemos responder, pero si podemos suponer con certeza a partir del texto que, muchas de las dominaciones estatales construidas a partir de las revoluciones burguesas responden al tipo carismático bajo su forma plebiscitaria, que, en definitiva, es el que de alguna manera el que el autor esperaba para la Alemania de 1919(27).

\section{Señala Weber que}

En caso de racionalización creciente de las relaciones de la asociación, ocurre con facilidad que este reconocimiento sea considerado como fundamento de legitimidad en vez de consecuencia de la legitimidad (legitimidad democrática); que la (eventual) designación por el cuadro administrativo sea considerada como "preelección", la realizada por los predecesores como "propuesta electoral", y el reconocimiento mismo por la comunidad como "elección". El señor legítimo en méritos de su propio carisma se transforma en imperante por la gracia de los dominados, que éstos por su arbitrio (formalmente) libre eligen y ponen, y eventualmente, deponen también - como ya antes- la pérdida del carisma y la falta de corroboración traían por consecuencia la pérdida de la legitimidad genuina (2002, p. 214).

O sea, que lo que en el carisma típico aparecía como un deber de reconocimiento aquí se transforma, por el uso de un conjunto de medios racionales de selección de la dirigencia, en una elección de los dominados del líder carismático: "El imperante es ahora jefe libremente elegido" dice. La elección funciona a nuestro entender como una forma de reactualización del carisma, al modo de las necesarias cuando una dominación carismática se extiende en el tiempo (supuestos de rutinización).

Consideramos que los llamados populismos son un ejemplo por antonomasia de estos fenómenos, al margen de los señalados por el autor, ya que “(...) el imperante se sienta(e) legitimado como el hombre de confianza de las masas y sea (es) como tal reconocido" y "el medio adecuado para ello es el plebiscito (...) es formalmente el medio específico de derivar la legitimidad de la dominación de la

(27) Debemos decir, sin embargo, que Weber no es tan "popular", por otra parte, pensamos que no pudo imaginar la relevancia que tendría el carisma en nacional socialismo alemán. Al respecto véanse las consideraciones de Arendt al inicio del capítulo X de Los orígenes del totalitarismo. 
confianza libérrima (formalmente y según la ficción) de los dominados" (Weber, 2002, p. 214).

El líder populista - de derecha o de izquierda puesto que el populismo es una forma de articulación de lo político según Laclau - tiene la posibilidad de operar transformaciones revolucionarias en el sentido weberiano porque encarna, además, la síntesis de un conjunto de demandas heterogéneas pero de las cuales él aparece como único sujeto capaz de sintetizar y, a la vez, es un significante vacío, lo que para nosotros es un ejemplo de la "ficción" mentada por Weber: vivir en una democracia pero devaluada, de masas.

Weber dice claramente que

La "democracia plebiscitaria" - el tipo más importante de la democracia de jefes- es, según su sentido genuino, una especie de dominación carismática oculta bajo la forma de una legitimidad derivada de la voluntad de los dominados y sólo por ella perdurable. El jefe (demagogo) domina de hecho en virtud de la devoción y confianza personal de su séquito político (2002, p. 215).

Un tipo en el cual podemos reconocer a los gobiernos de Juan Domingo Perón en Argentina o de Hugo Chávez en Venezuela. Los populismos, además, devienen en lo que Weber señala como una "forma menos precisa de administrar" pero probablemente "más democrática" y "más revolucionaria" o sea, más alejada del "polo institucional" (28), menos apegadas al estatuto y el expediente que la "democracia sin jefes" o "la dominación de 'políticos profesionales' sin vocación" a la que tanto le teme Weber (1982, p. 346).

La emotividad; la "justicia de carácter material" pero no del todo rigurosa; el reclutamiento carismático del cuadro administrativo (o de sus principales componentes); la idea de burocracia "electiva" y no profesional; la idea del "dictador social"; cierta despreocupación de las consecuencias en pos del "proyecto" como dogma o máxima de la acción; también “(...) la transformación radical de la situación de mando absoluto del líder carismático en la de un 'servidor' de los dominados (...)" que se compadece con slogans del tipo "el candidato es el proyecto", resultan un catálogo de elementos para analizar la realidad actual lo que consolida la idea de Weber como autor "clásico".

Ahora, si los líderes carismáticos plebiscitarios son quienes aparecen al frente de las democracias por elección "pasiva" o un tanto ornamental de las masas contemporáneas, la pregunta que queda pendiente es ¿existe una dominación

(28) Lo opuesto al populismo. 
legítima puramente racional legal? ¿Es la democracia "sin caudillos" de la que habla Weber, una especie de gobierno a lo De la Rúa?

\section{Palabras finales}

Weber advierte que el "llamado", el "verdadero caudillo", tal vez podría equilibrar los componentes no absolutamente opuestos de las dos éticas, la de la convicción y la de la responsabilidad:

Sólo quien está seguro de no quebrarse cuando, desde su punto de vista, el mundo se muestra demasiado estúpido o demasiado abyecto para lo que él le ofrece; sólo quien frente a todo esto es capaz de responder con un "sin embargo"; sólo un hombre construido de esta forma tiene "vocación" para la política (1982, pp. 362-364).

Quienes posean las cualidades para responder al llamado serán sencillamente héroes, conjugando la vocación que sienten con las cualidades necesarias para desempeñar la profesión que eligieron, para no convertirse en diletantes. Tendrán, si los acompaña la suerte, como dijo Maquiavelo, la posibilidad de trazar nuevos rumbos en la historia, por eso es importante el liderazgo carismático incluso en la actualidad, para no caer en una democracia sin liderazgo, para no caer en el legado de Bismark.

Todos los y las políticos profesionales, incluso los carentes de carisma, deben igualmente actuar con pasión y mesura para no convertirse en burócratas y asumir que deben dar cuentas de lo que hacen, no sólo el sentido actual de responsabilidad "judicial" de sus actos, sino para con la historia.

La actualidad del pensamiento de Max Weber en el centenario de "La política como vocación" que es también, casi, el centenario de su muerte está presente no sólo en el campo académico sino en la política contemporánea. Tal vez, las referencias a la ética de la política son las más visibles en el análisis en nuestro tiempo. Sólo a título de ejemplo, se ha dicho en el caso de Raúl Alfonsín, que buscó un equilibrio entre el legítimo reclamo entre justicia y la necesaria preservación del sistema democrático, un equilibrio entre la ética de la convicción y ética de la responsabilidad (Quiroga, 2005, p. 29). También está presente en el discurso de asunción Néstor Kirchner a la presidencia de la Nación, el 25 de mayo de 2003, cuando dijo:

Formo parte de una generación diezmada, castigada con dolorosas ausencias, me sumé a las luchas políticas con valores y convicciones a las que no pienso dejar en la puerta de entrada de la Casa Rosada. No creo en el axioma de que cuando se gobierna se cambia convicción 
por pragmatismo, eso constituye en verdad un ejercicio de hipocresía y cinismo (29) (Política Argentina, 2003).

La política es una actividad extraordinaria, con consecuencias extraordinarias también, quien se atreve a seguir su canto de sirena debe tener una conciencia de sí como muy superior a su vanidad.

\section{Bibliografía}

Arendt, H. (1998). Los orígenes del totalitarismo. Madrid: Taurus. (Original (1951). The origins of the totalitarianism).

Aron, R. (1979). Introducción. En M. Weber, El político y el científico. Madrid: Alianza.

Bourdieu, P. (2002). Razones prácticas. Sobre la teoría de la acción. Barcelona: Anagrama.

Giddens, A. (2002). Política y sociología en Max Weber. Madrid: Alianza.

Ginzberg, V. (2013). El juicio puso en riesgo y a la vez consolidó la democracia. Página 12. Recuperado de https://www.paginal2.com.ar/diario/elpais/1-235209-2013-12-08.html [Fecha de consulta: 21/03/2019].

Laclau, E. (2010). Discurso, antagonismo y hegemonía. En A. García Linera, E. Laclau, y G. O'Donnell, Tres pensamientos políticos. Buenos Aires: UBA Sociales Publicaciones.

Política Argentina. El discurso de Kirchner, N. cuando asumió (25/05/2003). Recuperado de https://www.politicargentina.com/notas/201505/5810-a-12-anosde-la-asuncion-de-nestor-kirchner-como-presidente.html [Fecha de consulta: 21/03/2019].

Quiroga, H. (2005). La Argentina en emergencia permanente. Buenos Aires: Edhasa.

Weber, M. (1982). La política como vocación. En M. Weber, Escritos Políticos II (pp. 308-364). F. Rubio Llorente (Trad.). México: Folios Ediciones. (Original alemán (1919). Politik als beruf).

(29) Véase también la entrevista a su hijo Ricardo Alfonsín realizada por Victoria Ginsberg (Política Argentina, 2013). 
Weber, M. (2002). Economía y Sociedad. Esbozo de una sociología comprensiva. J. Medina Echavarría (Trad.). Madrid: Fondo de Cultura Económica. (Original en alemán (1922). Wirtschaft und Gesellschaft. Grundriss der Vmtehendn Soziologie).

Fecha de recepción: 01-04-2019

Fecha de aceptación: 05-09-2019 